\title{
UPAYA MENINGKATKAN MOTIVASI BELAJAR SISWA MELALUI METODE DISKUSI KELOMPOK PADA KOMPETENSI DASAR POLITIK LUAR NEGERI INDONESIA MATA PELAJARAN PKN KELAS IV SD NEGERI 060819 KEC. MEDAN KOTA
}

\author{
Lasma Situmorang \\ Surel: lasmasitumorang@gmail.com
}

\begin{abstract}
ABSTRAK
Penelitian ini bertujuan untuk meningkatkan motivasi belajar siswa Kelas IV SD Negeri 060819 Kec. Medan Kota.T.P 2017/2018 pada mata pelajaran PKn. Penelitian ini adalah penelitian tindakan kelas. Subjek penelitian ini siswa Kelas IV SD 060819 Kec. Medan Kota.tahun ajaran 2017/2018 berjumlah 32 orang siswa. Instrumen yang digunakan adalah lembar format observasi guru dan motivasi belajar siswa. Hasil temuan penelitian diperoleh pada siklus I pertemuan pertama terdapat $18,7 \%$ siswa yang termotivasi dalam belajar sedangkan $81,3 \%$ siswa masih kurang termotivasi dalam belajar. Pada pertemuan kedua siklus I terdapat $46,9 \%$ siswa yang termotivasi sedangkan $53,1 \%$ siswa masih kurang termotivasi dalam belajar. Dengan demikian secara klasikal siswa dinyatakan masih kurang termotivasi dalam belajar. Setelah dilakukan perbaikan, pada pertemuan pertama siklus II meningkat menjadi 90,6\% dan pada pertemuan kedua siklus II meningkat menjadi 93,8\%. Sementara siswa yang kurang termotivasi pada pertemuan pertama siklus II sebanyak 9,4\% dan pada pertemuan kedua siklus II sebanyak 6,2\%. Berdasarkan hasil temuan penelitian disimpulkan proses pembelajaran dengan menggunakan metode diskusi kelompok dapat meningkatkan motivasi belajar siswa Kelas IV SD Negeri 060819 Kec. Medan Kota.T.P 2017/2018 pada mata pelajaran PKn materi pokok politik luar negeri Indonesia.
\end{abstract}

Kata Kunci: Motivasi Belajar, Metode Diskusi Kelompok, PKN

\section{PENDAHULUAN}

Pendidikan kewarganegaran (PKn) termasuk pelajaran bidang ilmu pengetahuan sosial yang mempelajari teori-teori serta perihal sosial yang ada di sekitar lingkungan masyarakat. Pendidikan terbentuknya

Pendidikan Kewarganegaran (PKn) termasuk pelajaran bidang ilmu pengetahuan sosial yang mempelajari teori-teori serta perihal sosial yang ada di sekitar lingkungan masyarakat. Pendidikan Kewarganegaraan pada hakikatnya merupakan pendidikan yang mengarah pada terbentuknya warga negara yang baik dan bertanggung jawab berdasarkan nilainilai dan dasar negara Pancasila.

$$
\text { Kaitannya }
$$

dengan pembentukan warga negara yang baik dan bertanggung jawab, mata pelajaran 
Kewarganegaraan (PKn) memiliki peranan yang strategis dan penting dalam dunia pendidikan, yaitu dalam membentuk pribadi siswa maupun sikap dalam berperilaku keseharian, sehingga diharapkan setiap individu mampu menjadi pribadi yang baik. Melalui mata pelajaran PKn ini, diharapkan siswa sebagai warga negara dapat mengkaji dan memahami hak, kewajiban dan tanggung jawabnya sebagai warga negara. Berkaitan dengan tujuan pendidikan nasional maka pembangunan dalam dunia pendidikan perlu ditingkatkan dan melalui pembelajaran PKn akan ditanamkan moral yang baik pada diri siswa dari sejak dini.

Rendahnya hasil belajar PKn siswa dapat disebabkan oleh beberapa faktor antara lain: 1) guru masih cenderung menggunakan metode ceramah dan kurang melibatkan siswa aktif dalam belajar; 2) sebagian besar siswa memandang mata pelajaran PKn sebagai mata pelajaran yang bersifat konseptual dan teoritis sehingga ketika mengikuti proses pembelajaran merasa cukup mencatat dan menghafal; 3) praktek kehidupan di masyarakat seringkali berbeda dengan wacana yang dikembangkan dalam proses pembelajaran di kelas (misalnya saat belajar di dalam kelas guru menganjurkan kepada siswa untuk selalu menjaga kebersihan, tidak membuang sampah sembarang, menghormati orang yang lebih tua dan lain sebagainya, tetapi pada praktek di dalam kehidupan nyata siswa banyak melihat orang yang lebih dewasa melakukan hal yang berbeda dengan apa yang disampaikan gurunya) akibatnya siswa seringkali merasa apa yang dipelajari dalam proses pembelajaran di kelas sebagai hal yang sia-sia; dan 4) selama proses pembelajaran guru kurang memberikan motivasi kepada siswa sehingga siswa merasa kurang termotivasi dan semangat dalam belajar.

Pada dasarnya, banyak cara yang dapat digunakan guru untuk mempengaruhi proses belajar menjadi efektif dan efisien, salah satu diantaranya adalah dengan menumbuhkan motivasi belajar pada diri siswa. Untuk dapat mendorong dan menumbuhkan motivasi siswa dalam belajar, guru harus mampu menemukan metode pembelajaran yang tepat. Salah satu metode yang dianggap tepat dan sesuai dalam menumbuhkan atau meningkatkan motivasi siswa dalam belajar adalah dengan menggunakan metode diskusi kelompok. Hal ini sejalan dengan yang dikemukakan Suryosubroto (1997:181), bahwa "teknik diskusi sebagai metode belajar mengajar lebih cocok dan diperlukan jika guru hendak mengembangkan motivasi siswa untuk belajar lebih lanjut". Penggunaan metode diskusi pada 
pelajaran PKn diharapkan dapat meningkatkan motivasi belajar siswa yang akhirnya dapat meningkatkan hasil belajar yang optimal.

Berdasarkan uraian-uraian di atas, peneliti tertarik melakukan suatu penelitian tindakan kelas dengan mengangkat judul

$$
\text { "Upaya Meningkatkan }
$$

Motivasi Belajar Siswa Melalui Metode Diskusi Kelompok pada Kompetensi Dasar Politik luar negeri Indonesia Mata Pelajaran PKn Kelas IV SD Negeri 060819 Kec. Medan Kota T.A. 2017/2018".

Berdasarkan uraian latar belakang di atas, dapat diidentifikasi beberapa masalah, antara lain:

1. Sebagian besar siswa SD Negeri 060819 Kec. Medan Kota memandang mata pelajaran PKn sebagai mata pelajaran yang bersifat konseptual dan teoritis (hafalan) sehingga siswa kurang termotivasi dalam belajar PKn.

2. Selama proses pembelajaran PKn di dalam kelas guru kurang melibatkan siswa secara aktif dalam belajar dan kurang memberikan motivasi kepada siswa sehingga siswa merasa kurang termotivasi dan semangat dalam belajar

3. Metode mengajar yang digunakan guru masih kurang variatif dan cenderung menggunakan metode ceramah dan berpusat pada buku.
Agar permasalah yang diteliti tidak terlalu meluas perlu dilakukan pembatasan masalah. Masalah yang diteliti dalam penelitian ini dibatasi pada meningkatkan motivasi belajar siswa dengan menggunakan metode diskusi kelompok pada mata pelajaran PKn materi pokok politik luar negeri Indonesia di Kelas IV SD Negeri 060819 Kec. Medan Kota T.P 2017/2018.

Manfaat yang diharapkan dari hasil penelitian ini antara lain:

1. Bagi siswa, untuk dapat meningkatkan motivasi siswa dalam belajar melalui penggunaan metode diskusi kelompok.

2. Bagi guru sebagai bahan pertimbangan dan umpan balik dalam meningkatkan motivasi belajar PKn siswa melalui metode diskusi kelompok.

3. Sebagai bahan usul kenaikan pangkat satu tingkat

\section{METODE PENELITIAN}

Penelitian ini termasuk jenis Penelitian Tindakan Kelas (PTK). Ciri khas PTK adalah adanya siklussiklus yang merupakan suatu pemecahan menuju praktek pembelajaran yang lebih baik. Penelitian dilakukan di SD Negeri 060819 Kec. Medan Kota. Waktu penelitian dilakukan pada semester genap tahun ajaran 2017/2018 selama 3 bulan mulai bulan Maret hingga Mei 2017. Subjek dalam penelitian ini 
adalah siswa Kelas IV SD Negeri 060819 Kec. Medan Kota tahun ajaran 2017/2018 sebanyak 1 kelas yaitu 32 orang siswa.

\section{Siklus I}

1. Perencanaan

Pada tahap perencanaan, guru bersama guru kelas membahas teknis pelaksanaan penelitian tindakan kelas yang akan dilakukan, antara lain:

a. Menyusun RPP sebanyak dua kali pertemuan pada materi politik luar negeri Indonesia meliputi: standar kompetensi, kompetensi dasar, indikator,

b. tujuan pembelajaran, langkahlangkah pembelajaran menggunakan metode diskusi kelompok, sumber belajar dan penilaian.

c. Membuat format lembar observasi tentang motivasi belajar siswa dan kegiatan guru selama proses pembelajaran berlangsung.

d. Menyusun tes untuk mengukur hasil belajar siswa.

2. Pelaksanaan Tindakan

Kegiatan yang dilakukan pada tahap ini antara lain:

a. Guru meminta siswa untuk membentuk kelompok diskusi terdiri dari 5 orang tiap kelompok. b. Guru menjelaskan indikator dan tujuan pembelajaran dari materi yang akan dipelajari.

c. Guru menjelaskan aturan dari diskusi kelompok yang akan dilakukan.

d. Guru menjelaskan secara singkat konsep politik luar negeri Indonesia

e. Guru memberikan atau mengajukan beberapa permasalah tentang politik luar negeri Indonesia untuk didiskusikan dalam kelompok masaing-masing.

f. Guru membimbing para siswa melakukan diskusi kelas membahas masalah yang diberikan.

g. Guru memberikan kesempatan yang sama kepada setiap siswa dalam diskusi untuk bertanya, dan mengeluarkan ide atau pendapatnya.

h. Guru tetap mengendalikan agar pembicaraan atau diskusi tetap pada pokok permasalahan yang sedang dibahas. Hal ini dilakukan agar masalah yang didiskusikan atau dibahas tidak menjadi melebar dan tetap fokus.

i. Guru membimbing para siswa untuk membuat kesimpulan dari hasil pembelajaran. 
3. Observasi

Observasi $\begin{array}{r}\text { dilakukan } \\ \text { tindakan }\end{array}$
selama proses dibantu guru Kelas
berlangsung
IV selaku mitra kolaborasi untuk
mengamati segala aktivitas yang
terjadi selama proses
pembelajaran menggunakan
format lembar observasi yang
telah disiapkan.

4. Refleksi

Refleksi dilakukan berdasarkan hasil analisis data observasi di dalam kelas tentang motivasi siswa dalam belajar dan pelaksanaan pembelajaran yang dilakukan oleh guru. Hasil refleksi ini kemudian digunakan sebagai dasar untuk perencanaan pada siklus selanjutnya.

\section{Siklus II}

1. Perencanaan

Perencanaan siklus II dilakukan berdasarkan refleksi yang diperoleh pada siklus I untuk memperbaiki langkah-langkah pembelajaran yang akan dilakukan. Adapun perencanan tersebut meliputi:

a. Menyusun ulang rancangan pembelajaran dalam bentuk RPP sebanyak dua kali pertemuan pada materi politik luar negeri Indonesia meliputi: standar kompetensi, kompetensi dasar, indikator, tujuan pembelajaran, langkahlangkah perbaikan pembelajaran menggunakan metode diskusi kelompok, sumber belajar dan penilaian.

b. Membuat format lembar observasi tentang motivasi belajar siswa dan kegiatan guru selama proses pembelajaran berlangsung.

c. Menyusun tes untuk mengukur hasil belajar siswa.

2. Pelaksanaan Tindakan

Pada tahap ini kegiatan yang dilaksanakan adalah melaksanakan skenario kegiatan yang telah direncanakan sebagai perbaikan dan pengembangan dari siklus I. Secara umum kegiatan yang dilakukan antara lain:

a. Membentuk ulang kelompok diskusi secara heterogen terdiri dari 5 orang tiap kelompok.

b. Menjelaskan indikator dan tujuan pembelajaran yang akan dipelajari.

c. Menjelaskan aturan dari diskusi kelompok yang akan dilakukan.

d. Mengajukan beberapa permasalahan tentang politik luar negeri Indonesia untuk didiskusikan dalam kelompok masing-masing. 
e. Membimbing dan memotivasi para siswa selama melakukan diskusi kelas membahas masalah yang diberikan.

f. Memberikan kesempatan yang sama kepada setiap siswa dalam diskusi untuk bertanya, dan mengeluarkan ide atau gagasannya.

g. Menghargai pertanyaan dan pendapat siswa.

h. Mengendalikan agar pembicaraan atau diskusi tetap pada pokok permasalahan yang sedang dibahas. Hal ini dilakukan agar masalah yang didiskusikan atau dibahas tidak menjadi melebar dan tetap fokus.

i. Memberikan pujian kepada kelompok yang berhasil dalam diskusi, dan memotivasi kelompok siswa yang belum berhasil untuk lebih giat belajar.

j. Membimbing para siswa untuk membuat kesimpulan dari hasil pembelajaran.

3. Observasi dan Evaluasi

Kegiatan observasi
dilakukan selama proses
pembelajaran siklus II dan tetap
dibantu oleh guru Kelas IV di
tempat penelitian sebagai mitra
kolaborasi untuk mengamati
segala aktivitas yang terjadi di
dalam kelas.

4. Refleksi

$$
\text { Kegiatan }
$$

refleksi dilaksanakan pada akhir pertemuan selama siklus II dengan mengamati secara rinci segala yang terjadi di kelas pada pertemuan siklus II.

Pengumpulan data pada penelitian ini dilakukan menggunakan format lembar observasi yang terdiri dari dua bagian yaitu:

1. Lembar observasi tentang motivasi belajar siswa

2. Lembar observasi tentang pelaksanaan penelitian yang dilakukan oleh guru menggunakan metode diskusi kelompok.

Observasi dilakukan selama proses pembelajaran di dalam kelas. Pelaku observasi dalam penelitian ini adalah guru kelas Kelas IV SD Negeri 060819 Kec. Medan Kota selaku mitra kolaborasi. Selama proses pembelajaran berlangsung guru kelas mengambil posisi atau tempat yang strategis agar dapat mengamati seluruh aktivitas yang terjadi khususnya yang berhubungan dengan motivasi belajar siswa menggunakan lembar format observasi yang telah dipersiapkan.

Dalam penelitian tindakan kelas, data yang dikumpulkan dapat berbentuk data kuantitatif (berupa angka-angka) maupun data kualitatif (berupa kata, kalimat, dan narasi). Teknik analisis data yang digunakan 
sesuai dengan data yang dikumpulkan. Data penelitian ini dianalisis sebagai berikut:

1. Penilaian Skor Motivasi Belajar Siswa Secara Individu Indikator motivasi belajar yang diamati sebanyak 7 indikator dan tiap indikator terdiri dari 3 deskriptor atau secara keseluruhan terdapat 21 aspek yang diamati. Dengan demikian, skor tertinggi untuk keseluruhan aspek adalah 21 (jika seluruh aspek teramati) dan skor terendah adalah 1 (jika tidak satupun aspek yang teramati).

Kriteria Motivasi Siswa Secara Individual:

Motivasi Kurang:Skor 0 s/d 5

Motivasi Cukup:Skor 6 s/d 11

Motivasi Baik:Skor 12 s/d 17

Motivasi Baik Sekali:Skor 18 s/d 21

2. Motivasi Belajar Siswa Secara Klasikal

Secara klasikal atau kelas siswa dinyatakan telah mencapai motivasi belajar yang baik jika 85\% siswa telah memperoleh kategori cukup, baik dan baik sekali. Motivasi belajar siswa secara klasikal (MK) dihitung dengan cara:

Kriteria Motivasi Klasikal:

MK $<85 \%$ : Secara kelas siswa dinyatakan belum termotivasi dalam belajar

MK $\geq 85 \%$ : Secara kelas siswa dinyatakan telah termotivasi dalam belajar

3. Persentase Motivasi Belajar Secara Keseluruhan

Persentase motivasi belajar siswa secara keseluruhan dihitung dengan menggunakan rumus sebagai berikut: $\mathrm{P}=\frac{\mathrm{f}}{\mathrm{N}} \times 100 \%$

Keterangan:

$\mathrm{P}=$ Persentase subjek yang diamati

$\mathrm{f}=$ Jumlah subjek yang diamati

$\mathrm{N}=$ Jumlah subjek keseluruhan

\section{HASIL DAN PEMBAHASAN}

Berdasarkan hasil pengamatan mitra kolaborasi tentang motivasi belajar siswa pada pertemuan pertama siklus I yaitu sebanyak 26 orang $(81,3 \%)$ siswa yang memiliki motivasi tergolong kurang, 5 orang $(15,6 \%)$ tergolong motivasi cukup dan 1 orang $(3,1 \%)$ memiliki motivasi yang tergolong baik.

Selanjutnya siswa dinyatakan telah termotivasi dalam belajar jika berada pada kriteria atau kategori cukup, baik dan baik sekali. Dari hasil pada Tabel 4, dapat dihitung 
persentase motivasi belajar siswa secara klasikal (MK), sebagai berikut:

$$
\begin{aligned}
& \mathrm{MK}=\frac{1+5}{32} \times 100 \% \\
& \mathrm{MK}=18,7 \%
\end{aligned}
$$

Kriteria Motivasi Klasikal:

$\begin{array}{rlr}\text { MK }<85 \%: & \text { Secara kelas siswa } \\ & \text { dinyatakan belum } \\ & \text { termotivasi dalam } \\ & \text { belajar } \\ \text { MK } \geq 85 \%: & \text { Secara kelas siswa } \\ & \text { dinyatakan telah } \\ & \text { termotivasi dalam } \\ & \text { belajar }\end{array}$

Berdasarkan hasil perhitungan dan kriteria motivasi belajar siswa secara klasikal diperoleh hanya 6 orang (5 orang cukup dan 1 orang tergolong baik) atau $18,7 \%$ siswa yang telah termotivasi dalam belajar dan jumlah ini masih kurang dari $85 \%$ sehingga secara klasikal atau kelas siswa dinyatakan masih belum termotivasi dalam belajar.

Berdasarkan hasil pengamatan

mitra kolaborasi (guru) pada pertemuan pertama siklus I, dapat dikemukakan bahwa penggunaan metode diskusi kelompok masih belum dapat memotivasi siswa dalam belajar. Selama proses pembelajaran pertemuan pertama siklus I hanya $18,7 \%$ siswa yang telah termotivasi dalam belajar sedangkan $81,3 \%$ siswa belum termotivasi dalam belajar.
Kurangnya motivasi siswa dalam belajar selama pertemuan pertama dikarenakan siswa masih belum terbiasa melakukan diskusi kelompok dan diskusi kelas sehingga masih banyak siswa yang kurang serius mengerjakan tugas, kurang antusias melakukan diskusi, terlalu cepat menyerah ketika menghadapi kesulitan, kurang berani mempertahankan pendapat, kurang menghargai pendapat temannya, kurang percaya diri menjawab maupun memberikan tanggapan dan kurangnya keberanian siswa bertanya kepada guru. Di samping itu, guru juga kurang berinteraksi dengan siswa, serta kurang membimbing, memotivasi siswa dalam diskusi, sehingga siswa kurang serius dan kurang termotivasi dalam melaksanakan diskusi karena tidak adanya penghargaan dan motivasi dari guru

Seperti yang telah direncanakan, tindakan siklus I dilaksanakan dalam dua kali pertemuan. Tindakan dilakukan di ruang Kelas IV SD Negeri No.060819 Medan Kota. Masing-masing pertemuan dilakukan selama $2 \times 35$ menit.

Pada tahap perencanaan siklus I untuk pertemuan kedua guru telah mempersiapkan skenario pembelajaran dalam bentuk RPP, menyiapkan format lembar observasi tentang motivasi belajar siswa dan 
kegiatan guru selama proses pembelajaran berlangsung dan menyiapkan tes untuk mengukur hasil belajar siswa setelah diberikan tindakan. Sebelumnya guru juga telah melakukan pertemuan dengan mitra kolaborasi membahas teknik pelaksanaan tindakan yang akan dilakukan terutama pelaksanaan observasi oleh mitra kolaborasi menggunakan format lembaran observasi yang disiapkan. Pada tahap perencanaan juga disepakati jadwal pelaksanaan yang akan dilakukan pada pertemuan kedua siklus I dilaksanakan.

Pertemuan kedua siklus I dilaksanakan dengan alokasi waktu 2 $\times 35$ menit. Tindakan dilakukan di ruang Kelas IV SD Negeri 060819 Kec. Medan Kota. Proses pembelajaran diawali dengan memberikan salam dan mengabsen kehadiran siswa. Para siswa membalas salam guru. Kemudian guru menjelaskan indikator dan tujuan dari pembelajaran yang akan dilakukan dilanjutkan dengan melakukan apersepsi dan memotivasi siswa agar memiliki kesiapan untuk belajar. Guru meminta siswa membentuk kelompok dan bergabung dengan kelompoknya masing-masing sesuai pertemuan sebelumnya. Selanjutnya menjelaskan secara singkat tentang politik luar negeri Indonesia.
Selanjutnya, guru memberikan kesempatan kepada kelompok lainnya untuk memberikan pertanyaan atau tanggapan dari presentasi kelompok penyaji. Siswa yang aktif bertanya dan mengajukan tanggapan wakil kelompok II, kelompok IV dan dari kelompok I. Selama diskusi kelas, guru berusaha mengendalikan agar diskusi tetap pada pokok permasalahan yang sedang dibahas, sehingga masalah yang didiskusikan atau dibahas tidak menjadi melebar dan tetap fokus. Sebelum mengakhiri pembelajaran guru memberikan pertanyaan-pertanyaan secara lisan kepada siswa untuk mengetahui pemahaman siswa setelah dilakukan diskusi. Kemudian membimbing siswa untuk membuat rangkuman pembelajaran dan memberikan tugas (PR) untuk masing-masing kelompok. Hasil pengamatan mitra kolaborasi tentang kegiatan guru selama pertemuan kedua siklus I dengan menggunakan metode diskusi kelompok, secara ringkas.

pertemuan kedua siklus I berdasarkan pengamatan mitra kolaborasi, kegiatan guru dalam mengelola kelas masih tergolong kurang. Menurut pengamat guru kurang berinteraksi dengan siswa sehingga masih banyak siswa yang kurang serius (tidak fokus) pada diskusi yang dilakukan, dan saat guru mengajukan pertanyaan, siswa cenderung menjawab pertanyaan dengan serentak sehingga suasana 
kelas sedikit ribut. Menurut pengamat, guru juga kurang memberikan penghargaan atau pujian bagi kelompok yang berhasil dalam diskusinya dan kurang memotivasi kelompok siswa yang masih kurang berhasil dalam diskusi, sehingga siswa kurang serius dan kurang termotivasi dalam melaksanakan diskusi karena tidak adanya penghargaan dan motivasi dari guru.

Selanjutnya, hasil pengamatan mitra kolaborasi tentang motivasi belajar siswa pada pertemuan kedua siklus I, secara ringkas.menunjukkan bahwa motivasi belajar siswa selama pertemuan kedua siklus I berdasarkan hasil pengamatan mitra kolaborasi (guru kelas), sebanyak 17 orang $(53,1 \%)$ siswa masih memiliki motivasi yang tergolong kurang, 11 orang $(34,4 \%)$ memiliki motivasi tergolong cukup dan 4 orang $(12,5 \%)$ memiliki motivasi yang tergolong baik.

Selanjutnya siswa dinyatakan telah termotivasi dalam belajar jika berada pada kriteria atau kategori cukup, baik dan baik sekali. Dari hasil pertemuan kedua siklus I, dapat dihitung persentase motivasi belajar siswa secara klasikal (MK), sebagai berikut:

$\mathrm{MK}=\frac{11+4}{32} \times 100 \%$

$\mathrm{MK}=46,9 \%$
Berdasarkan hasil perhitungan dan kriteria motivasi belajar siswa secara klasikal diperoleh hanya 15 orang (11 orang cukup dan 4 orang tergolong baik) atau 46,9\% siswa yang telah termotivasi dalam belajar dan jumlah ini masih kurang dari $85 \%$ sehingga secara klasikal atau kelas pada pertemuan kedua siklus I siswa dinyatakan masih belum termotivasi dalam belajar.

Berdasarkan hasil pengamatan mitra kolaborasi (guru) selama pertemuan kedua siklus I, dapat dikemukakan bahwa penggunaan metode diskusi kelompok juga masih belum dapat memotivasi siswa dalam belajar secara optimal. Selama proses pembelajaran pertemuan kedua siklus I hanya $46,9 \%$ siswa yang telah termotivasi dalam belajar sedangkan $53,1 \%$ siswa masih belum termotivasi dalam belajar.

Kurangnya motivasi siswa dalam belajar selama pertemuan pertama dikarenakan siswa masih belum terbiasa melakukan diskusi kelompok dan diskusi kelas sehingga masih banyak siswa yang kurang serius mengerjakan tugas, kurang antusias melakukan diskusi, terlalu cepat menyerah ketika menghadapi kesulitan, kurang berani mempertahankan pendapat, kurang menghargai pendapat temannya, kurang percaya diri menjawab maupun memberikan tanggapan dan kurangnya keberanian siswa bertanya 
kepada guru. Di samping itu, guru juga kurang berinteraksi dengan siswa, serta kurang membimbing, memotivasi siswa dalam diskusi, sehingga siswa kurang serius dan kurang termotivasi dalam melaksanakan diskusi karena tidak adanya penghargaan dan motivasi dari guru. Oleh karena itu, maka siklus II sebagai perbaikan proses pembelajaran pada siklus I perlu dilaksanakan untuk lebih meningkatkan motivasi siswa dalam belajar

Sama halnya dengan pelaksanaan siklus I, pelaksanaan siklus II juga dilakukan selama 2 kali pertemuan, dan masing-masing pertemuan terdiri atas 4 tahapan yaitu tahap perencanaan, pelaksanaan tindakan, observasi dan refleksi.

Hasil pengamatan mitra kolaborasi tentang kegiatan guru selama pertemuan pertama siklus II, secara ringkas bahwa pada pertemuan pertama siklus II berdasarkan pengamatan mitra kolaborasi, kegiatan guru selama proses tindakan siklus II sudah tergolong baik. Selama proses tindakan guru telah memotivasi siswa selama melaksanakan diskusi kelompok dengan baik sekali, guru telah mengelola kelas dengan baik sekali sehingga pelaksanaan diskusi kelas berjalan dengan baik dan lancar, guru juga telah memberikan penghargaan atau pujian bagi kelompok yang berhasil dan tetap memotivasi kelompok siswa yang masih kurang berhasil dalam diskusi agar lebih giat belajar. Selama tindakan para siswa tampak antusias mengikuti proses pembelajaran yang dilakukan.

Selanjutnya, hasil pengamatan mitra kolaborasi tentang motivasi belajar siswa menunjukkan bahwa motivasi belajar siswa selama pertemuan pertama siklus II berdasarkan hasil pengamatan mitra kolaborasi (guru kelas), sebanyak 3 orang $(9,4 \%)$ siswa masih memiliki motivasi yang tergolong kurang, 16 orang $(50 \%)$ memiliki motivasi tergolong cukup dan 13 orang (40,6\%) memiliki motivasi yang tergolong baik.

Selanjutnya siswa dinyatakan telah termotivasi dalam belajar jika berada pada kriteria atau kategori cukup, baik dan baik sekali. Dari hasil pada Tabel 8, dapat dihitung persentase motivasi belajar siswa secara klasikal (MK), sebagai berikut:

$$
\begin{aligned}
& \mathrm{MK}=\mathrm{MK}=\frac{16+13}{32} \times 100 \% \\
& \mathrm{MK}=90,6 \%
\end{aligned}
$$

Berdasarkan hasil perhitungan dan kriteria motivasi belajar siswa secara klasikal diperoleh sebanyak 29 orang (16 orang cukup dan 13 orang tergolong baik) atau 90,6\% siswa yang telah termotivasi dalam belajar dan jumlah ini sudah lebih dari $85 \%$ sehingga secara klasikal atau kelas 
pada pertemuan pertama siklus II siswa dinyatakan sudah termotivasi dalam belajar.

Berdasarkan hasil pengamatan

mitra kolaborasi (guru) selama pertemuan pertama siklus II, dapat dikemukakan bahwa penggunaan metode diskusi kelompok sudah dapat memotivasi siswa dalam belajar. Selama proses pembelajaran pertemuan pertama siklus II sebanyak $90,6 \%$ siswa yang telah termotivasi dalam belajar sedangkan 9,4\% siswa yang masih belum termotivasi dalam belajar.

Meskipun telah memotivasi siswa untuk aktif dalam melakukan diskusi baik diskusi kelompok maupun diskusi kelas, masih terdapat 3 orang $(9,4 \%)$ siswa yang masih belum termotivasi dalam belajar. Selama melaksanakan diskusi kelompok ketiga siswa tersebut tampak pasif hanya mendengarkan temannya saat berdiskusi, guru sudah berusaha memotivasi siswa untuk aktif dalam diskusi dan meminta teman-temannya untuk mengajak dan membantu siswa tersebut agar aktif dalam diskusi, tetapi ketiga siswa tersebut hanya diam dan kurang menghiraukan guru dan temantemannya. Saat pelaksanaan diskusi kelas, guru juga sudah berusaha meminta ketiga siswa untuk bertanya maupun memberikan tanggapannya, namun ketiga siswa tersebut masih kurang berani atau malu, meskipun guru sudah berusaha memotivasi mereka untuk tidak malu atau takut jika pertanyaan atau tanggapannya salah.

Berdasarkan hasil pengamatan mitra kolaborasi tentang motivasi belajar siswa pada pertemuan kedua siklus II menunjukkan bahwa motivasi belajar siswa selama pertemuan kedua siklus II berdasarkan hasil pengamatan mitra kolaborasi (guru kelas), sebanyak 2 orang $(6,2 \%)$ siswa masih memiliki motivasi yang tergolong kurang, 7 orang $(21,9 \%)$ memiliki motivasi tergolong cukup, 20 orang $(62,5 \%)$ memiliki motivasi yang tergolong baik dan 3 orang $(9,4 \%)$ memiliki motivasi belajar yang tergolong baik sekali. Selanjutnya siswa dinyatakan telah termotivasi dalam belajar jika berada pada kriteria atau kategori cukup, baik dan baik sekali. Dari hasil pada Tabel 10, dapat dihitung persentase motivasi belajar siswa secara klasikal (MK), sebagai berikut:

$$
\begin{aligned}
& \mathrm{MK}=\frac{7+20+3}{32} \times 100 \% \\
& \mathrm{MK}=93,8 \%
\end{aligned}
$$

Berdasarkan hasil perhitungan dan kriteria motivasi belajar siswa secara klasikal diperoleh sebanyak 30 orang ( 7 orang cukup, 13 orang baik, dan 3 orang tergolong baik sekali) atau 93,8\% siswa yang telah termotivasi dalam belajar dan jumlah ini sudah 
lebih dari $85 \%$ sehingga secara klasikal atau kelas pada pertemuan kedua siklus II siswa dinyatakan sudah termotivasi dalam belajar.

Berdasarkan hasil pengamatan mitra kolaborasi (guru) selama pertemuan kedua siklus II, juga dapat dikemukakan bahwa penggunaan metode diskusi kelompok sudah dapat memotivasi siswa dalam belajar secara optimal. Selama proses pembelajaran pertemuan kedua siklus II sebanyak 93,8\% siswa yang telah termotivasi dalam belajar sedangkan $6,2 \%$ siswa yang masih belum termotivasi dalam belajar.

Meskipun telah memotivasi siswa untuk aktif dalam melakukan diskusi baik diskusi kelompok maupun diskusi kelas, masih terdapat 2 orang $(6,2 \%)$ siswa yang masih belum termotivasi dalam belajar. Selama melaksanakan diskusi kelompok kedua siswa tersebut tampak pasif hanya mendengarkan temannya saat berdiskusi, guru sudah berusaha memotivasi siswa untuk aktif dalam diskusi dan meminta teman-temannya untuk mengajak dan membantu siswa tersebut agar aktif dalam diskusi, tetapi kedua siswa tersebut hanya diam dan kurang menghiraukan guru dan temantemannya. Saat pelaksanaan diskusi kelas, guru juga sudah berusaha meminta kedua siswa untuk bertanya maupun memberikan tanggapannya, namun kedua siswa tersebut masih tetap kurang berani atau malu, meskipun guru sudah berusaha memotivasi mereka untuk tidak malu atau takut jika pertanyaan atau tanggapannya salah. Secara keseluruhan proses pembelajaran dengan menggunakan metode diskusi kelompok telah dapat memotivasi siswa dalam belajar.

\section{Pembahasan}

Penelitian yang dilakukan di SD Negeri 060819 Kec. Medan Kota bertujuan untuk meningkatkan motivasi belajar siswa dengan menggunakan metode diskusi kelompok pada mata pelajaran PKn materi pokok politik luar negeri Indonesia. Hasil penelitian menunjukkan bahwa dengan proses pembelajaran dengan menggunakan metode diskusi kelompok terbukti dapat meningkatkan motivasi belajar siswa pada mata pelajaran PKn materi pokok politik luar negeri Indonesia di Kelas IV SD Negeri 060819 Kec. Medan Kota T.P 2017/2018.

Peningkatan motivasi belajar siswa dapat dilihat dari perbandingan siklus I dan siklus II untuk masingmasing pertemuan. Pertemuan pertama siklus I terdapat $18,7 \%$ siswa yang termotivasi dalam belajar (15,6\% cukup dan $3,1 \%$ tergolong baik). Pada pertemuan kedua siklus I terdapat $46,9 \%$ siswa yang telah termotivasi dalam belajar $(34,4 \%$ cukup dan $12,5 \%$ tergolong baik). 
Setelah dilakukan perbaikan pembelajaran, pada pertemuan pertama siklus II sebanyak 90,6\% siswa yang telah termotivasi dalam belajar (50\% cukup dan 40,6\% tergolong baik). Pada pertemuan kedua siklus II sebanyak 93,8\% siswa yang telah termotivasi dalam belajar (21,9\% cukup, $62,5 \%$ baik dan $9,4 \%$ tergolong baik sekali).

\section{Pada siklus I hingga}

pertemuan kedua terdapat $46,9 \%$ siswa yang telah termotivasi dalam belajar, sedangkan $53,1 \%$ siswa masih belum termotivasi dalam belajar. Kurangnya motivasi siswa dalam belajar dapat dilihat dari kurangnya ketekunan siswa mengerjakan tugas, kurangnya antusias siswa melakukan diskusi, terlalu cepat menyerah ketika menghadapi kesulitan, kurang berani mempertahankan pendapat, kurang menghargai pendapat teman, kurang percaya diri menjawab maupun memberikan tanggapan dan kurangnya keberanian siswa bertanya kepada guru.

Proses pembelajaran dengan metode diskusi kelompok belum dapat memotivasi siswa dalam belajar dikarenakan selama ini siswa kurang dilatih untuk berdiskusi sehingga masih banyak siswa yang tampak kurang serius dalam melaksanakan diskusi. Hal ini sejalan dengan pendapat Sagala (2009:209) yang mengemukakan bahwa kelemehan- kelemahan metode diskusi antara lain:

1) diskusi terlampau menyerap waktu;

2) pada umumnya siswa tidak berlatih untuk melakukan diskusi dan menggunakan waktu diskusi dengan baik maka kecenderungannya para siswa tidak sanggup berdiskusi; dan 3) kadang-kadang guru tidak memahami cara-cara melaksanakan diskusi, maka kecenderungannya diskusi menjadi tanya jawab.

Berdasarkan pendapat di atas, penggunaan metode diskusi kurang mampu memotivasi siswa dalam belajar dikarenakan diskusi yang dilakukan cenderung menjadi proses tanya jawab dalam kelas. Selama pelaksanaan tindakan siklus I berdasarkan hasil pengamatan mitra kolaborasi, guru kurang mampu mengelola kelas dengan baik, kurang memberikan penghargaan atau pujian bagi kelompok yang berhasil dalam diskusinya dan kurang memotivasi kelompok siswa yang masih kurang berhasil dalam diskusi, sehingga siswa kurang serius dan kurang termotivasi dalam melaksanakan diskusi karena tidak adanya penghargaan dan motivasi dari guru.

Setelah dilakukan perbaikan pembelajaran pada siklus II dengan tetap menggunakan metode diskusi kelompok, dengan lebih memberikan motivasi kepada siswa selama melaksanakan diskusi kelompok, pengelolaan kelas yang baik, memberikan penghargaan atau pujian 
bagi kelompok yang berhasil dalam diskusinya dan tetap memotivasi kelompok siswa yang masih kurang berhasil dalam diskusi agar lebih giat belajar terbukti dapat meningkatkan motivasi siswa dalam belajar, dimana jumlah siswa yang telah termotivasi dalam belajar selama tindakan siklus II hingga pertemuan kedua meningkat menjadi 93,8\% siswa yang telah termotivasi dalam belajar, meskipun demikian masih terdapat $6,2 \%$ siswa yang masih kurang termotivasi dalam belajar. Namun, secara klasikal atau kelas siswa dinyatakan telah termotivasi dalam belajar.

Berdasarkan hasil temuan penelitian menunjukkan bahwa proses pembelajaran dengan menggunakan metode diskusi kelompok terbukti dapat meningkatkan motivasi siswa dalam belajar. Hal ini juga sejalan dengan yang dikemukakan oleh Suryosubroto (1997:181), bahwa "teknik diskusi sebagai metode belajar mengajar lebih cocok dan diperlukan jika guru hendak mengembangkan motivasi siswa untuk belajar lebih lanjut".

Dengan demikian, dari hasil penelitian dan teori yang ada maka disimpulkan bahwa proses pembelajaran dengan menggunakan metode diskusi kelompok dapat meningkatkan motivasi belajar siswa Kelas IV SD Negeri 060819 Kec. Medan Kota T.P 2017/2018 pada mata pelajaran PKn materi pokok politik luar negeri Indonesia.

\section{SIMPULAN}

Berdasarkan hasil penelitian, analisis dan refleksi dari tiap-tiap siklus dikemukakan beberapa kesimpulan yaitu pada proses pembelajaran dengan menggunakan metode diskusi kelompok dapat meningkatkan motivasi belajar siswa Kelas IV SD Negeri 060819 Kec. Medan Kota T.P 2017/2018 pada mata pelajaran PKn materi pokok politik luar negeri Indonesia. Pada siklus I pertemuan pertama terdapat $18,7 \%$ siswa yang telah termotivasi dalam belajar sedangkan $81,3 \%$ siswa masih kurang termotivasi dalam belajar. Pada pertemuan kedua siklus I terdapat $46,9 \%$ siswa yang telah termotivasi dalam belajar sedangkan $53,1 \%$ siswa masih kurang termotivasi dalam belajar. Dengan demikian secara klasikal siswa dinyatakan masih kurang termotivasi dalam belajar. Setelah dilakukan perbaikan pembelajaran pada siklus II, siswa yang telah termotivasi dalam belajar, pada pertemuan pertama siklus II meningkat menjadi $90,6 \%$ dan pada pertemuan kedua siklus II meningkat menjadi $93,8 \%$. Sementara siswa yang kurang termotivasi dalam belajar pada pertemuan pertama siklus II sebanyak 9,4\% dan pada pertemuan kedua siklus II sebanyak $6,2 \%$. Dengan demikian, secara 
klasikal atau kelas siswa dinyatakan telah termotivasi dalam belajar.

Sebagai tindak lanjut dari kesimpulan-kesimpulan di atas, diajukan beberapa saran sebagai berikut:

1. Kepada siswa diharapkan untuk selalu menumbuhkan motivasi dalam belajar, aktif berdiskusi, tidak perlu malu atau takut salah untuk bertanya, menjawab pertanyaan maupun mengungkapkan pendapat.

2. Kepada guru PKn diharapkan untuk lebih memahami berbagai metode mangajar yang dapat digunakan di dalam kelas terutama dalam rangka meningkatkan motivasi belajar siswa.

\section{DAFTAR RUJUKAN}

Aqib, Z. 2006. Peneltian Tindakan

Kelas Untuk Guru. Bandung: Yrama Widya.

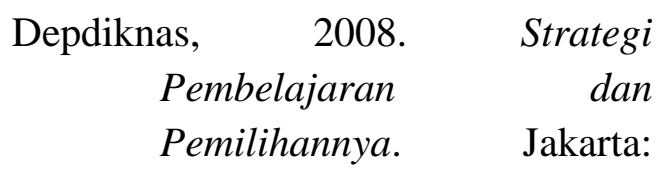

$\begin{array}{lr}\text { Direktorat } & \text { Jenderal } \\ \text { Peningkatan } & \text { Mutu } \\ \text { Pendidikan dan Tenaga } & \text { Tenartemen } \\ \text { Kependidikan, Departem Nasional. } & \end{array}$

Dimyati dan Mudjiono. 2006. Belajar dan Pembelajaran. Jakarta: Rineka Cipta.

Djamarah, S.B, dan Zain, A. 2002. Strategi Belajar Mengajar. Jakarta: Rineka Cipta.

Hamalik, O. 2001. Kurikulum dan Pembelajaran. Jakarta: Bumi Aksara.

Sagala, S., 2009. Konsep dan Makna Pembelajaran, Untuk Membantu Memecahkan Problematika Belajar dan Mengajar. Bandung: Alfabeta.

Sardiman, A.M., 2006. Interaksi dan Motivasi Belajar Mengajar. Jakarta: Rajawali Pers.

Syah, M., 2003. Psikologi Belajar. Jakarta: Raja Grafindo Pers. 